\title{
PERAN KEPUASAN KONSUMEN MEMEDIASI PENGARUH BRAND IMAGE TERHADAP REPURCHASE INTENTION
}

\author{
I G. A. Pt. Riana Pramesti Dewi ${ }^{1}$ \\ Ni Wayan Ekawati ${ }^{2}$ \\ ${ }^{1,2}$ Fakultas Ekonomi dan Bisnis Universitas Udayana, Bali, Indonesia \\ email: rianapramesti@gmail.com
}

\begin{abstract}
ABSTRAK
Tujuan penelitian ini adalah untuk memberikan penjelasan mengenai pengaruh brand image terhadap kepuasan konsumen, pengaruh brand image dan kepuasan konsumen terhadap repurchase intention, serta peranan kepuasan konsumen dalam memediasi hubungan brand image dengan repurchase intention. Penelitian ini dilangsungkan di Kota Denpasar dengan menyebarkan kuesioner kepada sampel penelitian yaitu sebanyak 112 responden yang dipilih melalui teknik purposive sampling. Indikator dari penelitian ini sebanyak 16 butir yang dianalisis menggunakan analisis Path, Uji Sobel, dan Uji VAF. Hasil dari penelitian ini menerangkan bahwa brand image berpengaruh secara positif yang juga signifikan kepada kepuasan konsumen, brand image dan juga kepuasan konsumen berpengaruh secara positif serta juga signifikan kepada repurchase intention, selanjutnya kepuasan konsumen mampu memediasi hubungan antara brand image terhadap repurchase intention. Implikasi teoritis dari penelitian ini adalah bahwa brand image dapat meningkatkan kepuasan konsumen sehingga mampu meningkatkan repurchase intention konsumen. Implikasi praktis dalam penelitian ini adalah manajemen perusahaan harus memberikan perhatian yang lebih terhadap brand image dan kepuasan konsumen karena hal tersebut merupakan faktor yang dapat memicu munculnya repurchase intention.
\end{abstract}

Kata kunci: brand image, kepuasan konsumen, repurchase intention

\begin{abstract}
The purpose of this study is to provide an explanation of the influence of brand image on consumer satisfaction, the influence of brand image and customer satisfaction on repurchase intention, and the role of consumer satisfaction in mediating the relationship between brand image and repurchase intention. This research was conducted in Denpasar city by distributing questionnaires to the research sample as many as 112 respondents who were selected through purposive sampling technique. The indicators of this study were 16 items which were analyzed using Path analysis, Sobel Test, and VAF Test. The results of this study explain that brand image has a positive effect that is also significant for consumer satisfaction, brand image and also customer satisfaction positively and significantly influence repurchase intention, then consumer satisfaction is able to mediate the relationship between brand image and repurchase intention. The theoretical implication of this study is that brand image can increase consumer satisfaction so as to increase consumer intention to repurchase. The practical implication in this research is that company management must pay more attention to brand image and customer satisfaction because this is a factor that can trigger the emergence of repurchase intention.
\end{abstract}

Keywords: brand image, customer satisfaction, repurchase intention 


\section{PENDAHULUAN}

Manusia merupakan makhluk hidup yang memiliki banyak kebutuhan, salah satunya adalah makanan dan minuman. Berbicara mengenai minuman, dengan pesatnya perkembangan zaman, saat ini berbagai minuman mulai mengalami perkembangan yang cukup pesat misalnya saja dari cara penyajian, komposisi atau kandungan yang ada pada minuman tersebut, serta varian rasa yang beragam yang dimana hal tersebut dapat saja merupakan salah satu dampak dari adanya globalisasi yang membuat para produsen minuman berlomba-lomba melakukan inovasi untuk menciptakan sesuatu yang unik yang berbeda dari yang lainnya demi menghindari konsumen dari kejenuhan dan menarik perhatian konsumen untuk terus mengulang pembelian. Menurut Diponugroho dan Santoso (2015) konsumen yang merasakan selalu ada suatu inovasi dalam suatu hal, cenderung berniat untuk terus melakukan pembelian ulang. Menurut Varga et al. (2014) minat beli ulang atau repurchase intention dapat diperoleh dengan cara membangun serta menjalin hubungan dengan baik serta selalu menyajikan nilai dan juga meningkatkan rasa puas pada konsumen. Menurut Choi dan Kim (2013), tingkat kepuasan membuat konsumen mempunyai niat yang semakin kuat untuk mengulang suatu pembelian. Pupuani dan Sulistyawati (2013) serta Kusuma dan Suryani (2017) dalam penelitiannya mengatakan bahwa kepuasan konsumen rupanya berpengaruh secara positif yang juga signifikan terhdap minat beli ulang. Akan tetapi, hasil lainnya ditemukan Prastiwi (2016) bahwa kepuasan konsumen tak berdampak signifikan terhadap repurchase intention. Hal tersebut menandakan 
I G. A. Pt. Riana Pramesti Dewi, Peran Kepuasan Konsumen Memediasi...

bahwa konsumen yang mendapatkan kepuasan belum juga tentu memiliki niat melakukan pembelian ulang terhadap produk yang sama.

Umumnya, konsumen lebih menyukai produk dengan merek yang lebih dikenal luas dipasaran meskipun harga yang ditawarkan cenderung lebih mahal (Tjiptono dalam Herliza dan Saputri (2016). Menurut Yana dkk. (2015) brand atau merek dapat memberikan janji bahwa produk yang dibeli atau dikonsumsi konsumen pada waktu itu dapat memberi rasa puas sehingga konsumen bersedia untuk membeli kembali produk yang sama di lain waktu. Perusahaan yang secara merek produknya lebih dikenal dan baik secara publik, tentunya akan memiliki tempat yang baik juga di pasar dan akan dapat mempertahankan keunggulan kompetitifnya serta dapat meningkatkan nilai dari pangsa pasar (Shahroudi dan Naimi, 2014). Moksaoka dan Rahyuda (2016) mengatakan bahwa melalui suatu brand image, konsumen akan dapat mengenali produk, melakukan evaluasi terhadap produk, meminimalisir resiko pembelian serta mendapatkan pengalaman dan kepuasan dari diferensiasi produk. Apabila tanggapan konsumen mengenai suatu produk yang ditawarkan oleh berbagai perusahaan adalah memberikan fungsi dan manfaat yang sama bagi konsumen, maka konsumen akan melihat dari brand yang dimiliki oleh perusahaan atau produk tersebut dengan persepsi dan tanggapan yang berbeda-beda. Herliza dan Saputri (2016) dalam penelitiannya mendapatkan hasil bahwa kepuasan konsumen dipengaruhi oleh brand image dengan positif dan signifikan. Oleh sebab itu, pembentukan suatu image terhadap suatu brand produk ataupun perusahaan merupakan sesuatu yang harus diberi perhatian lebih karena hal tersebut rupanya berdampak nyata pada sikap dan 
perilaku konsumen. Brand image yang baik dan terpercaya akan memberikan rasa aman pada diri konsumen yang kemudian membuat konsumen semakin tertarik melakukan pembelian pada produk yang ditawarkan dari brand tersebut (Pechyiam dan Jaroenwanit, 2014). Ain dan Ratnasari (2015) serta Soleha dkk. (2017) dalam penelitiannya mengungkapkan ada pengaruh yang positif dan juga sigifikan dari brand image terhadap repurchase intention atau minat beli ulang. Semakin baiknya image yang dimiliki oleh suatu brand, mampu menaikkan minat konsumen dalam melakukan pembelian kembali.

Salah satu jenis minuman yang sedang banyak digandrungi dan juga memiliki brand image yang cukup baik dalam benak konsumen adalah Chatime. Chatime merupakan minuman kekinian yang berasal dari Taiwan yang pada umumnya berbahan dasar teh yang dikombinasikan dengan berbagai macam varian rasa serta dalam penyajiannya ditambahkan isian berupa topping. Chatime pertama kali hadir di Indonesia pada tahun 2011 tepatnya bulan Februari, dan pada September 2017 yang lalu Chatime merayakan atas keberhasilan pembukaan 200 gerai di Indonesia yang mana merupakan jumlah gerai terbanyak di Negara manapun termasuk mengalahkan Negara asalnya. Hal tersebut menyatakan bahwa Chatime sangat berhasil di Indonesia dan berdasarkan antusiasme konsumen dari awal keberadaan Chatime, membuat Chatime banyak mendirikan gerainya di daerah-daerah di Indonesia, salah satunya Bali. Chatime hadir di Bali pada Maret 2012 dengan lokasi pertama adalah di Mall Bali Galeria, akan tetapi seiring berjalannya waktu dan dengan pesatnya perkembangan Chatime di Bali, Chatime juga membuka banyak gerai di Denpasar. Hal tersebut menandakan bahwa Kota 
I G. A. Pt. Riana Pramesti Dewi, Peran Kepuasan Konsumen Memediasi...

Denpasar memiliki potensi yang kuat untuk meningkatkan keuntungan Chatime dan memiliki banyak konsumen yang potensial.

Chatime menjadi salah satu brand minuman yang berhasil mendapatkan predikat Top Brand pada kategori Bubble Drink pada tahun 2017 hingga 2018 dan bahkan pada tahun-tahun sebelumnya.

Tabel 1.

Top Brand Index Kategori Bubble Drink tahun 2017 dan 2018

\begin{tabular}{cccccc}
\hline \multicolumn{2}{l}{$\mathbf{2 0 1 7}$} & \multicolumn{3}{c}{$\mathbf{2 0 1 8}$} \\
\hline Merek & TBI (\%) & TOP & Merek & TBI (\%) & TOP \\
\hline Chatime & 46,6 & TOP & Chatime & 44,9 & TOP \\
Hop-Hop & 22,5 & TOP & Hop-Hop & 30,7 & TOP \\
Lup-Lup & 5,8 & & Lup-Lup & 6,3 & \\
Quickly & 3,2 & & Quickly & 2,0 & \\
Sumber: Top Brand Award 2017 dan 2018
\end{tabular}

Berdasarkan hasil riset yang tertera pada Tabel 1, dapat diamati bahwa Chatime selalu menjadi peringkat pertama dalam kategorinya. Akan tetapi apabila dilihat persentase dari Top Brand Index (TBI) Chatime mengalami penurunan. Hal tersebut dapat mengindikasikan bahwa brand image Chatime yang mungkin saja sudah mulai melemah dalam benak konsumen mengingat Chatime bukanlah produk yang baru lagi dipasaran atau mungkin saja terjadi ketidakpuasan yang dirasakan konsumen terhadap Chatime sehingga konsumen lebih memilih produk sejenis dari merek lainnya. Hal tersebut tentunya sedikit banyak akan dapat berpengaruh bagi konsumen dalam rangka untuk melakukan pembelian ulang terhadap Chatime. Untuk mengetahui seberapa besar minat beli ulang konsumen terhadap Chatime, peneliti telah melakukan studi pendahuluan di Kota Denpasar dengan metode pra survei menggunakan kusioner sementara yang disebarkan kepada 30 orang responden yang mana dalam kuesioner tersebut berisi 
pernyataan-pernyataan mengenai variabel brand image, kepuasan konsumen, dan repurchase intention. Berdasarkan hasil pra survei, rupanya konsumen memiliki minat beli ulang yang sangat tinggi terhadap Chatime. Akan tetapi apabila dilihat dari hasil pra survei, rupanya brand image yang dimiliki Chatime kurang mampu memicu munculnya minat beli ulang konsumen terhadap Chatime jika dilihat dari hasil pra survei ini, sedangkan untuk kepuasan konsumen rupanya memberikan pengaruh yang sangat kuat untuk menimbulkan minat beli ulang pada konsumen terhadap Chatime mengingat kepuasan konsumen adalah salah satu faktor yang dapat mendorong munculnya repurchase intention terhadap suatu produk. Akan tetapi terdapat penelitian yang mengatakan bahwa kepuasan konsumen tidak berpengaruh secara signifikan terhadap repurchase intention, sehingga perlu dilakukan penelitian lebih lanjut menggunakan variabel-variabel ini dan menambahkan kepuasan konsumen sebagai variabel pemediasi hubungan antara brand image dengan repurchase intention.

Rumusan masalah dalam penelitian ini yaitu 1) bagaimana pengaruh brand image terhadap kepuasan konsumen pada produk Chatime di Kota Denpasar; 2) bagaimana pengaruh brand image terhadap repurchase intention pada produk Chatime di Kota Denpasar; 3) bagaimana pengaruh kepuasan konsumen terhadap repurchase intention pada produk Chatime di Kota Denpasar; 4) bagaimana peran kepuasan konsumen memediasi hubungan brand image dengan repurchase intention pada produk Chatime di Kota Denpasar. Tujuan dalam penelitian ini adalah memberikan jawaban terkait rumusan masalah yang diajukan. Manfaat penelitian ini secara teoritis diharapkan dapat memberikan manfaat bagi 
I G. A. Pt. Riana Pramesti Dewi, Peran Kepuasan Konsumen Memediasi...

pendidikan khususnya manajemen pemsaran serta bisa menjadi sarana referensi dalam penelitian yang akan datang. Manfaat penelitian ini secara praktis diharapkan dapat menjadi pedoman bagi manajemen Chatime dan produsen minuman lainnya untuk mengembangkan strategi pemasarannya masing-masing.

Brand image dapat dikatakan sebagai suatu bentuk persepsi atau pemahaman yang muncul dalam benak konsumen mengenai suatu brand secara keseluruhan dan dapat mempengaruhi perilaku konsumen dalam melakukan pembelian. Image yang baik dapat menjadi aset bagi suatu perusahaan untuk kedepannya, karena dengan image baik yang dimiliki maka akan mempengaruhi tanggapan dan persepsi konsumen terhadap suatu produk (Arimbawa dan Ekawati, 2017). Astuti (2016) menyatakan bahwa brand image merupakan representasi berdasarkan keseluruhan tanggapan atau persepsi pada suatu merek produk yang terbentuk dari informasi serta pengalaman masa lampau pada merek yang bersangkutan. Dengan terciptanya brand image yang baik, akan mampu membuat konsumen untuk melihat perbedaan antar produk.

Kepuasan konsumen dapat dikatakan sebagai tingkatan dari perasaan konsumen sesudah melakukan perbandingan ataupun mengevaluasi apa yang diterima dengan harapan yang dimiliki konsumen setelah mengkonsumsi suatu produk dimana apabila hasil yang didapatkan sudah sesuai ataupun melebihi harapannya maka konsumen akan merasa puas, sedangkan apabila hasil yang didapatkannya tidak sesuai harapan, maka konsumen tidak akan merasa puas. Dasar dari adanya kepuasan dapat berupa adanya pengalaman konsumen dari hubungan antara perusahaan atau organisasi dan hasil yang diperoleh konsumen 
(Cengiz, 2010). Wijaya dan Nurcaya (2017) berpendapat bahwa kepuasan konsumen merupakan perasaan konsumen dimana konsumen merasakan hal terbaik yang diberikan dari suatu perusahan. Pelanggan yang puas dengan hasil yang diperoleh dari suatu produk baik barang ataupun jasa, kemungkinan besar akan menjadi pelanggan setia (Darmawan dan Ekawati, 2017).

Minat pembelian ulang atau repurchase intention merupakan perilaku konsumen yang menujukkan rasa ingin untuk kembali bertransaksi atau membeli suatu produk yang sama yang pernah dibeli sebelumnya pada waktu yang akan datang. Minat beli ulang tentunya timbul setelah konsumen melakukan pembelian atau bertransaksi terhadap suatu produk. Menurut Ardhanari dalam Palaguna dan Ekawati (2016), repurchase intention dapat berupa situasi dimana seseorang sebelum bertindak, yang akan menjadi dasar untuk melakukan prediksi terhadap tindakan tersebut. Minat beli ulang juga merupakan suatu faktor yang dapat berpengaruh terhadap hubungan konsumen dengan perusahaan. Menurut Prastyaningsih dkk. (2014), minat beli ulang merupakan suatu hasrat yang muncul dalam diri konsumen untuk bersedia melakukan pembelian ulang kepada suatu produk, baik berupa barang ataupun jasa yang sama yang dilatarbelakangi dari kepuasan dan kepercayaan. Repurchase intention juga berguna untuk memberikan prediksi hubungan konsumen dengan perusahaan serta keuntungan bagi perusahaan atau sebaliknya Meng et al. (2011). Nikbin et al. (2011) menyatakan bahwa repurchase intention merupakan faktor yang dapat memberikan pengaruh terhadap hubungan antara konsumen dengan perusahaan di masa depan, keuntungan, serta kesuksesan perusahaan. 
I G. A. Pt. Riana Pramesti Dewi, Peran Kepuasan Konsumen Memediasi...

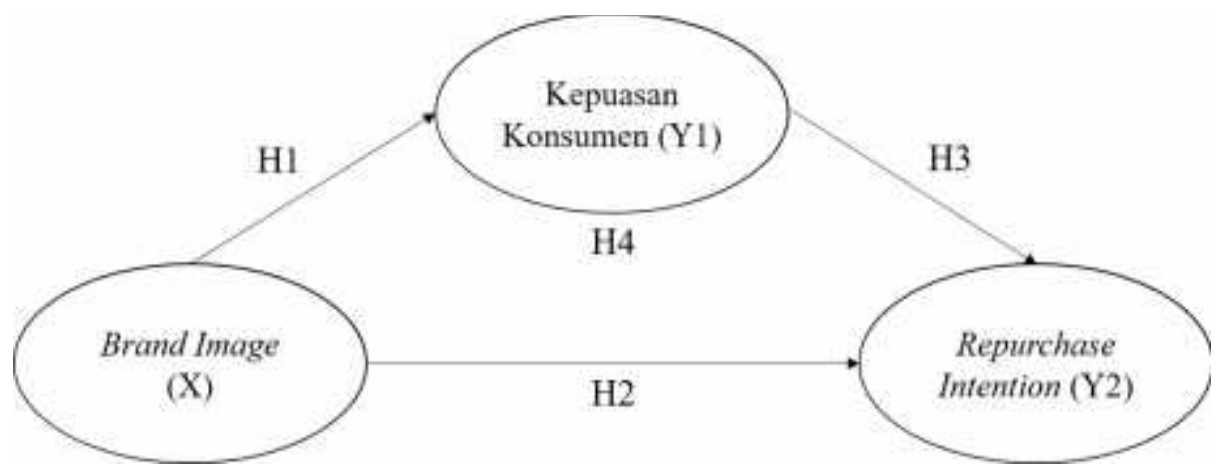

Gambar 1. Kerangka Konseptual Penelitian

Sumber: dikembangkan dari penelitian sebelurnnya, 2018

Berdasarkan penelitian yang dilakukan oleh Shahroudi dan Naimi (2014), Damayanti dan Wahyono (2015), Yana dkk. (2015), serta Herliza dan Saputri (2016), didapatkan hasil bahwa ada hubungan yang positif dan juga signifikan dari brand image dengan kepuasan konsumen. Dengan adanya brand image yang baik maka dapat meningkatkan kepuasan konsumen, dan sebaliknya. Brand image yang baik memberikan dampak bagi rasa emosional dalam diri konsumen yang akan menimbulkan perasaan positif yang disertai keyakinan pada saat bertransaksi dengan suatu merek produk tertentu sehingga menimbulkan rasa puas. Berdasarkan hasil-hasil penelitian tersebut, dapat dirumuskan hipotesis penelitian yaitu:

$\mathrm{H}_{1}$ : Brand image berpengaruh positif signifikan terhadap kepuasan konsumen pada produk chatime di kota Denpasar

Berdasarkan penelitian yang telah dilakukan oleh Carrasco dan Foxal dalam Thakur dan Singh (2012), citra merek merupakan salah satu variabel yang digunakan dalam mengukur repurchase intention. Chen dan Hsieh (2011), Ayutthaya (2013), Ain dan Ratnasari (2015), Soleha dkk. (2017), serta Sari dan 
Santika (2017) dalam penelitiannya menerangkan bahwa variabel citra merek atau brand image mempunyai pengaruh yang signifikan serta positif pada niat pembelian berulang. Dengan baiknya image yang dimiliki suatu brand yang dipersepsikan baik juga oleh konsumen, akan dapat mendorong semakin tingginya keinginan atau niatan konsumen untuk kembali berhubungan atau bertransaksi yang dalam hal ini adalah melakukan pembelian ulang terhadap brand tersebut. Berdasarkan hasil-hasil penelitian tersebut, dapat dirumuskan hipotesis penelitian, yaitu:

$\mathrm{H}_{2}$ : Brand image berpengaruh positif signifikan terhadap repurchase intention pada produk Chatime di Kota Denpasar

Kepuasan konsumen akan menjadi penyebab penting dibalik terjadinya pembelian ulang suatu produk tertentu. Ranjbarian et al. (2012) menyatakan bahwa ditemukan pengaruh yang signifikan antara kepuasan terhadap minat pembelian ulang. Ketika kepuasan pelanggan tinggi, akan ada kemungkinan besar konsumen akan mengkonsumsi produk baik barang ataupun jasa yang sudah pernah dibelinya pada waktu yang akan datang. Berdasarkan hasil analisis dalam penelitian Wang dan Lin (2010), Curtis et al. (2011), Pupuani dan Sulistyawati (2013), Huang et al. (2014), serta Kusuma dan Suryani (2017) diperoleh hasil bahwa kepuasan konsumen berpengaruh positif dan signifikan terhadap repurchase intention. Dengan tingginya rasa puas yang dirasakan konsumen yang diberikan oleh suatu produk, maka akan berpotensi juga untuk mendorong timbulnya niatan konsumen untuk mengulang pembelian pada produk tersebut di kemudian hari karena mendapatkan kesan positif yang dalam hal ini berupa 
I G. A. Pt. Riana Pramesti Dewi, Peran Kepuasan Konsumen Memediasi...

kepuasan pada pengalaman sebelumnya. Berdasarkan hasil-hasil penelitian tersebut, dapat dirumuskan hipoteseis penelitian yaitu:

$\mathrm{H}_{3}$ : Kepuasan konsumen berpengaruh positif signifikan terhadap repurchase intention pada produk Chatime di Kota Denpasar

Berdasarkan $\mathrm{H}_{1}, \mathrm{H}_{2}$, dan $\mathrm{H}_{3}$ yang menggunakan penelitian-penelitian terdahulu sebagai acuan dalam menarik hipotesis penelitian, maka dapat dikatakan bahwa ditemukan hubungan yang saling memberikan pengaruh antar variabel yaitu brand image, kepuasan konsumen dan repurchase intention. Susanti dan Wardana (2015) pada penelitiannya mengungkapkan bahwa terdapat pengaruh yang positif antara brand image atau citra merek dengan kepuasan konsumen. Image berperan untuk memasarkan suatu organisasi karena memiliki potensi yang dapat memberikan pengaruh terhadap persepsi dan ekspektasi konsumen terkait suatu produk yang kemudian akan dapat memberikan pengaruh terhadap rasa puas pada konsumen. Kepuasan konsumen memberikan dorongan pada hasrat konsumen untuk mengulang pembelian (Choi dan Kim, 2013). Hasil penelitian yang dilakukan oleh Suandana dkk. (2016) serta Oktarini dan Wardana (2018) juga mendukung pernyataan tersebut yang dalam penelitiannya mendapatkan hasil bahwa kepuasan konsumen mempunyai pengaruh yang positif terhadap repurchase intention dan juga signifikan. Savitri dan Wardana (2018) dalam penelitiannya berhasil mengungkap bahwa kepuasan konsumen mampu memediasi hubungan antara brand image terhadap repurchase intention. Hal ini menyatakan bahwa brand image menggerakkan kepuasan konsumen. Kepuasan konsumen diyakini sebagai pendorong repurchase intention pada konsumen. 
Berdasarkan hasil-hasil penelitian tersebut, dapat ditarik hipotesis penelitian terakhir dalam penelitian ini yaitu:

$\mathrm{H}_{4}$ : Kepuasan konsumen mampu memediasi pengaruh brand image terhadap repurchase intention pada produk Chatime di Kota Denpasar

\section{METODE PENELITIAN}

Penelitian ini digolongkan ke dalam bentuk asosiatif karena memiliki tujuan untuk mencari tahu hubungan brand image dengan repurchase intention melalui kepuasan konsumen sebagai variabel pemediasi. Lokasi penelitian adalah Kota Denpasar dengan objek penelitian adalah repurchase intention pada produk Chatime yang dipengaruhi oleh brand image serta kepuasan konsumen. Variabel independen pada penelitian ini yaitu brand image $(\mathrm{X})$ serta variabel dependen pada penelitian ini adalah kepuasan konsumen $\left(\mathrm{Y}_{1}\right)$ yang juga sebagai variabel pemediasi, dan repurchase intention $\left(\mathrm{Y}_{2}\right)$.

Tabel 2.

Rangkuman Instrumen Penelitian

\begin{tabular}{|c|c|c|}
\hline Variabel & Indikator & Referensi \\
\hline $\begin{array}{l}\text { Brand Image } \\
\text { (X) }\end{array}$ & $\begin{array}{l}\mathrm{X}_{1} \text { Recognition } \\
\mathrm{X}_{2} \text { Reputation } \\
\mathrm{X}_{3} \text { Affinity } \\
\mathrm{X}_{4} \text { Strengthness } \\
\mathrm{X}_{5} \text { Uniqueness } \\
\mathrm{X}_{6} \text { Favorable }\end{array}$ & $\begin{array}{l}\text { Dwiputranto } \\
\text { (2017), Herliza } \\
\text { dan Saputri } \\
\text { (2016) }\end{array}$ \\
\hline Kepuasan & $\mathrm{Y}_{1.1}$ Menciptakan word of mouth & Damayanti dan \\
\hline $\begin{array}{l}\text { Konsumen } \\
\quad\left(\mathrm{Y}_{1}\right)\end{array}$ & $\begin{array}{l}\mathrm{Y}_{1.2} \text { Pengalaman yang menyenangkan } \\
\mathrm{Y}_{1.3} \text { Pilihan yang tepat } \\
\mathrm{Y}_{1.4} \text { Kualitas produk } \\
\mathrm{Y}_{1.5} \text { Emotional factor } \\
\mathrm{Y}_{1.6} \text { Harga }\end{array}$ & $\begin{array}{l}\text { Wahyono (2015), } \\
\text { Lee (2010), } \\
\text { Darmawan dan } \\
\text { Ekawati }(2017)\end{array}$ \\
\hline $\begin{array}{l}\text { Repurchase } \\
\text { Intention } \\
\left(\mathrm{Y}_{2}\right)\end{array}$ & $\begin{array}{l}\mathrm{Y}_{2.1} \text { Minat transaksional } \\
\mathrm{Y}_{2.2} \text { Minat referensial } \\
\mathrm{Y}_{2.3} \text { Minat preferensial } \\
\mathrm{Y}_{2.4} \text { Minat eksploratif }\end{array}$ & $\begin{array}{l}\text { Ain dan Ratnasari } \\
(2015), \text { Soleha } \\
\text { dkk. (2017) }\end{array}$ \\
\hline
\end{tabular}

Konsumen Chatime Kota Denpasar menjadi populasi pada penelitian ini yang mana jumlahnya tidak dapat dihitung secara pasti. 16 butir indikator 
I G. A. Pt. Riana Pramesti Dewi, Peran Kepuasan Konsumen Memediasi...

digunakan pada penelitian ini yang berarti jumlah sampel yang dibutuhkan adalah minimal 80 (5x16) dan maksimal 160 (10x16). Penelitian ini menggunakan sampel sebanyak 112 orang responden yang berarti sudah memenuhi kriteria. Teknik purposive sampling diterapkan untuk menentukan sampel pada penelitian ini. Adapun data dalam penelitian ini bersifat kuantitatif dan kualitatif serta bersumber primer dan sekunder. Kuesioner digunakan untuk mengumpulkan data dalam penelitian ini yang dimana pengukuran atas jawaban responden menggunakan Skala Likert.

Penelitian ini menggunakan analisis jalur atau Path Analysis untuk mencari tahu hubungan antara variabel yang satu terhadap variabel penelitian yang lain, serta menggunakan Uji Sobel dan Uji VAF untuk menguji hipotesis mediasi.

Persamaan Sub Struktural 1

$$
\mathrm{Y}_{1}=\beta_{1} \mathrm{X}+\mathrm{e}_{1}
$$

Persamaan Sub Struktural 2

$$
\mathrm{Y}_{2}=\beta_{2} \mathrm{X}+\beta_{3} \mathrm{Y}_{1}+\mathrm{e}_{2}
$$

\begin{tabular}{|c|c|}
\hline$X$ & $=$ brand image \\
\hline $\mathrm{Y}_{1}$ & $=$ kepuasan konsumen \\
\hline $\mathrm{Y}_{2}$ & $=$ repurchase intention \\
\hline $\begin{array}{l}\beta_{1}, \beta_{2}, \beta_{3} \\
\mathrm{e}\end{array}$ & $\begin{array}{l}=\text { koefisien regresi variabel } \\
=\text { error }\end{array}$ \\
\hline
\end{tabular}

Keterangan :

\section{HASIL DAN PEMBAHASAN}

Data responden dalam penelitian ini dikelompokkan kedalam beberapa karakteristik. Klasifikasi responden berdasarkan jenis kelamin didominasi oleh perempuan dengan persentase 73 persen. Klasifikasi berdasarkan rentang usia didominasi oleh golongan remaja akhir yaitu usia 18-22 tahun dengan persentase 
94 persen. Berdasarkan pendidikan terakhir yang ditempuh didominasi oleh pendidikan terakhir SMA dengan persentase 82 persen. Berdasarkan status pekerjaan didominasi oleh karyawan swasta dengan persentase 53 persen.

Penelitian ini telah dilakukan uji validitas dengan mengamati nilai dari Pearson Correlation yang mana kriteria dinyatakan valid apabila nilai koefisien dari Pearson Correlation adalah lebih besar dari 0,30. Tabel 3 memaparkan bahwa berdasarkan uji validitas, keseluruhan instrumen penelitian dapat dikatakan valid, sehingga dapat dikatakan layak digunakan sebagai instrumen penelitian.

Tabel 3.

\begin{tabular}{cccc}
\multicolumn{3}{c}{ Rekapitulasi Hasil Uji Validitas Instrumen Penelitian } \\
\hline Variabel & Indikator & $\begin{array}{c}\text { Koefisien } \\
\text { Korelasi }\end{array}$ & Keterangan \\
\hline & $\mathrm{X}_{1}$ & 0,736 & Valid \\
Brand Image & $\mathrm{X}_{2}$ & 0,586 & Valid \\
$(\mathrm{X})$ & $\mathrm{X}_{3}$ & 0,635 & Valid \\
& $\mathrm{X}_{4}$ & 0,667 & Valid \\
& $\mathrm{X}_{5}$ & 0,765 & Valid \\
& $\mathrm{X}_{6}$ & 0,597 & Valid \\
& $\mathrm{Y}_{1.1}$ & 0,586 & Valid \\
Kepuasan Konsumen & $\mathrm{Y}_{1.2}$ & 0,846 & Valid \\
$\left(\mathrm{Y}_{1}\right)$ & $\mathrm{Y}_{1.3}$ & 0,714 & Valid \\
& $\mathrm{Y}_{1.4}$ & 0,677 & Valid \\
& $\mathrm{Y}_{1.5}$ & 0,687 & Valid \\
& $\mathrm{Y}_{1.6}$ & 0,596 & Valid \\
Repurchase Intention & $\mathrm{Y}_{2.1}$ & 0,738 & Valid \\
$\left(\mathrm{Y}_{2}\right)$ & $\mathrm{Y}_{2.2}$ & 0,790 & Valid \\
& $\mathrm{Y}_{2.3}$ & 0,698 & Valid \\
& $\mathrm{Y}_{2.4}$ & 0,710 & Valid \\
\hline
\end{tabular}

Sumber: Hasil olahan data, 2018

Penelitian ini juga telah melalui uji reliabilitas dengan mengamati nilai dari Cronbach's Alpha yang mana dinyatakan reliabel bila nilai dari Cronbach's Alpha $\geq 0,60$. Berdasarkan Tabel 4, dapat diamati bahwa seluruh instrumen penelitian memenuhi syarat reliabilitas yang kemudian dapat digunakan untuk meneliti. 
Tabel 4.

Rekapitulasi Hasil Uji Reliabilitas Instrumen Penelitian

\begin{tabular}{cccc}
\hline No & Variabel & Cronbadh'sAlpha & Keterangan \\
\hline 1 & Brand Image & 0,748 & Reliabel \\
2 & Kepuasan Konsumen & 0,768 & Reliabel \\
3 & Repurchase Intention & 0,694 & Reliabel \\
\hline
\end{tabular}

Sumber: Hasil olahan data, 2018

Uji normalitas telah dilakukan dalam penelitian ini dengan uji Kolmogorov Smirnov yang mana dikatakan data terdistribusi normal bila nilai Asymp. Sig. > 0,05 .

Tabel 5.

Hasil Uji Normalitas Struktur 1

\begin{tabular}{lc}
\hline & Unstandardized Residual \\
\hline $\mathrm{N}$ & 112 \\
Asymp. Sig. & 0,130 \\
Kolmogorov-Smirnov & \\
\hline Sumber: Hasil olahan data, 2018 &
\end{tabular}

Berdasarkan Tabel 5, nilai Asymp. Sig. (2-tailed) pada persamaan struktur 1 bernilai 0,130 sehingga dapat dikatakan berdistribusi normal karena nilai dari Asymp. Sig. > 0,05.

Tabel 6.

Hasil Uji Normalitas Struktur 2

\begin{tabular}{lc}
\hline & Unstandardized Residual \\
\hline $\mathrm{N}$ & 112 \\
Asymp. Sig. & 0,200 \\
Kolmogorov-Smirnov & \\
\hline Sumber: Hasil olahan data, 2018
\end{tabular}

Berdasarkan Tabel 6, nilai Asymp. Sig. (2-tailed) pada persamaan struktur 2 bernilai 0,200 yang juga dapat dikatakan berdistribusi normal dikarenakan nilai dari Asymp. Sig. > 0,05. 
Hasil dari uji multikolinearitas diamati dari nilai tolerance $>10$ persen serta nilai VIF $<10$. Berdasarkan Tabel 7 , nilai tolerance dan nilai VIF pada variabel bebas dalam masing-masing persamaan struktural memenuhi syarat dikatakan rnodel regresi yang bebas gejala multikolinearitas.

Tabel 7.

Hasil Uji Multikolinearitas

\begin{tabular}{llcc}
\hline \multicolumn{1}{c}{ Persamaan Struktur } & \multicolumn{1}{c}{ Variabel } & Tolerance & VIF \\
\hline $\mathrm{Y}_{1}=\beta_{1} \mathrm{X}+\mathrm{e}_{1}$ & Brand Image $(X)$ & 1,000 & 1,000 \\
$\mathrm{Y}_{2}=\beta_{2} \mathrm{X}+\beta_{3} \mathrm{Y}_{1}+\mathrm{e}_{2}$ & Brand Image $(X)$ & 0,429 & 2,330 \\
& Kepuasan & 0,429 & 2,330 \\
\hline Sumber: $\mathrm{Hansumen}\left(\mathrm{Y}_{1}\right)$ & &
\end{tabular}

Sumber: Hasil olahan data, 2018

Uji heteroskedastisitas dalam penelitian ini dilakukan dengan Uji Glejser yang kemudian dikatakan tidak terdapat gejala heteroskedastisitas dalam model penelitian apabila nilai signifikansinya diatas 0,05 .

Tabel 8.

Uji Heteroskedastisitas Struktur 1

\begin{tabular}{ccc}
\hline Model & Signifikansi & Keterangan \\
\hline Brand Image & 0,311 & Lolos Uji \\
\hline Sumber: Hasil olahan data, 2018 &
\end{tabular}

Tabel 8. memperlihatkan nilai signifikansi variabel bebas pada persamaan struktur 1 sebesar 0,311>0,05 yang mana dapat dinyatakan bahwa model penelitian yang dibuat tidak mengandung gejala heteroskedastisitas.

Tabel 9 memperlihatkan nilai signifikansi variabel-variabel bebas dalam persamaan struktur $2>0,05$ yaitu untuk brand image sebesar 0,284 dan untuk kepuasan konsumen sebesar 0,102. Hal tersebut juga menandakan bahwa model penelitian yang dibuat tidak mengandung gejala heteroskedastisitas. 
I G. A. Pt. Riana Pramesti Dewi, Peran Kepuasan Konsumen Memediasi...

Tabel 9.

Uji Heteroskedastisitas Struktur 1

\begin{tabular}{ccc}
\hline Model & Signifikansi & Keterangan \\
\hline $\begin{array}{c}\text { Brand Image } \\
\text { Kepuasan }\end{array}$ & 0,284 & Lolos Uji \\
Konsumen & 0,102 & Lolos Uji \\
\hline
\end{tabular}

Sumber: Hasil olahan data, 2018

Tabel 10.

Hasil Analisis Jalur I

\begin{tabular}{cccc}
\hline \multirow{2}{*}{ Variabel } & R Square & $\begin{array}{c}\text { Standardized } \\
\text { Coefficients }\end{array}$ & \multirow{2}{*}{ Sig. } \\
\cline { 3 - 3 } & & Beta & \\
\hline Brand Image & 0,571 & 0,756 & 0,000 \\
\hline
\end{tabular}

Sumber: Hasil olahan data, 2018

Berdasakan hasil analisis jalur pada persamaan struktur 1 yang dapat dilihat dalam Tabel 10, dapat dibentuk persamaan strukturalnya, yaitu sebagai berikut:

$\mathrm{Y}_{1}=\beta_{1} \mathrm{X}+\mathrm{e}_{1}$

$\mathrm{Y}_{1}=0,756 \mathrm{X}+\mathrm{e}_{1}$

Nilai koefisien $\beta_{1}$ sebesar 0,756 mengartikan bahwa variabel brand image mempunyai pengaruh yang positif kepada kepuasan konsumen. Nilai signifikansi 0,000<0,05 memperlihatkan bahwa adanya pengaruh yang signifikan atara brand image terhadap kepuasan konsumen. Nilai $\mathrm{R}$ square 0,571 berarti 57,1 persen variasi dari kepuasan konsumen dipengaruhi oleh brand image, dan sisanya dijelaskan dari faktor-faktor lainnya yang tidak disertakan pada penelitian.

Berdasarkan hasil dari analisis jalur pada persamaan struktur 2 yang dapat dilihat dalam Tabel 11, dapat dibentuk persamaan strukturalnya yaitu sebagai berikut:

$Y_{2}=\beta_{2} X+\beta_{3} Y_{1}+e_{2}$ 
$\mathrm{Y}_{2}=0,231 \mathrm{X}+0,593 \mathrm{Y}_{1}+\mathrm{e}_{2}$

Tabel 11.

Hasil Analisis Jalur II

\begin{tabular}{cccc}
\hline Variabel & R Square & $\begin{array}{c}\text { Standardized } \\
\text { Coefficients }\end{array}$ & Sig. \\
$\begin{array}{c}\text { Brand Image } \\
\text { Kepuasan } \\
\text { Konsumen }\end{array}$ & 0,613 & 0,231 & 0,012 \\
\hline $\begin{array}{l}\text { Sumber: Hasil olahan data, } 2018 \\
\text { Bumbera }\end{array}$ & 0,593 & 0,000 \\
\hline
\end{tabular}

Nilai koefisien regresi masing-masing variabel bebas yaitu $\beta_{2}$ dan $\beta_{3}$ masing-masing sebesar 0,231 serta 0,593 . Hal tersebut memiliki arti bahwa variabel brand image dan kepuasan konsumen berpengaruh positif terhadap repurchase intention. Nilai signifikansi variabel brand image yaitu 0,012<0,05 serta variabel kepuasan konsumen yaitu 0,000<0,05 yang mana memperlihatkan adanya pengaruh yang signifikan antara brand image serta kepuasan konsumen kepada repurchase intention. Nilai $\mathrm{R}$ square 0,613 memiliki arti bahwa sebesar 61,3 persen variasi dari repurchase intention dipengaruhi oleh brand image dan kepuasan konsumen, dan sisanya dijelaskan dari faktor-faktor lain yang tidak disertakan pada penelitian.

Berdasarkan substruktur 1 serta substruktur 2, dapat dihitung nilai dari masing-masing standar error yaitu :

$\mathrm{Pe}_{1}=\sqrt{1-R 1^{2}}$

$\mathrm{Pe}_{1}=\sqrt{1-0,571}=0,654$

$\mathrm{Pe}_{2}=\sqrt{1-R 2^{2}}$

$\mathrm{Pe}_{2}=\sqrt{1-0,613}=0,622$ 
I G. A. Pt. Riana Pramesti Dewi, Peran Kepuasan Konsumen Memediasi...

Berdasarkan perhitungan dari pengaruh error, dapat dilakukan perhitungan untuk koefisien determinasi total, yaitu sebagai berikut:

$$
\begin{aligned}
\mathrm{R}_{\mathrm{m}}^{2} & =1-\left(\mathrm{Pe}_{1}\right)^{2}\left(\mathrm{Pe}_{2}\right)^{2} \ldots \ldots \\
& =1-(0,654)^{2}(0,622)^{2} \\
& =0,834
\end{aligned}
$$

Nilai koefisien determinasi total berdasarkan perhitungan bernilai 0,834 yang berarti 83,4 persen variasi repurchase intention dipengaruhi oleh variasi brand image serta kepuasan konsumen, sementara 16,6 persen sisanya dijelaskan dari faktor lain yang tidak dijelasakan pada penelitian.

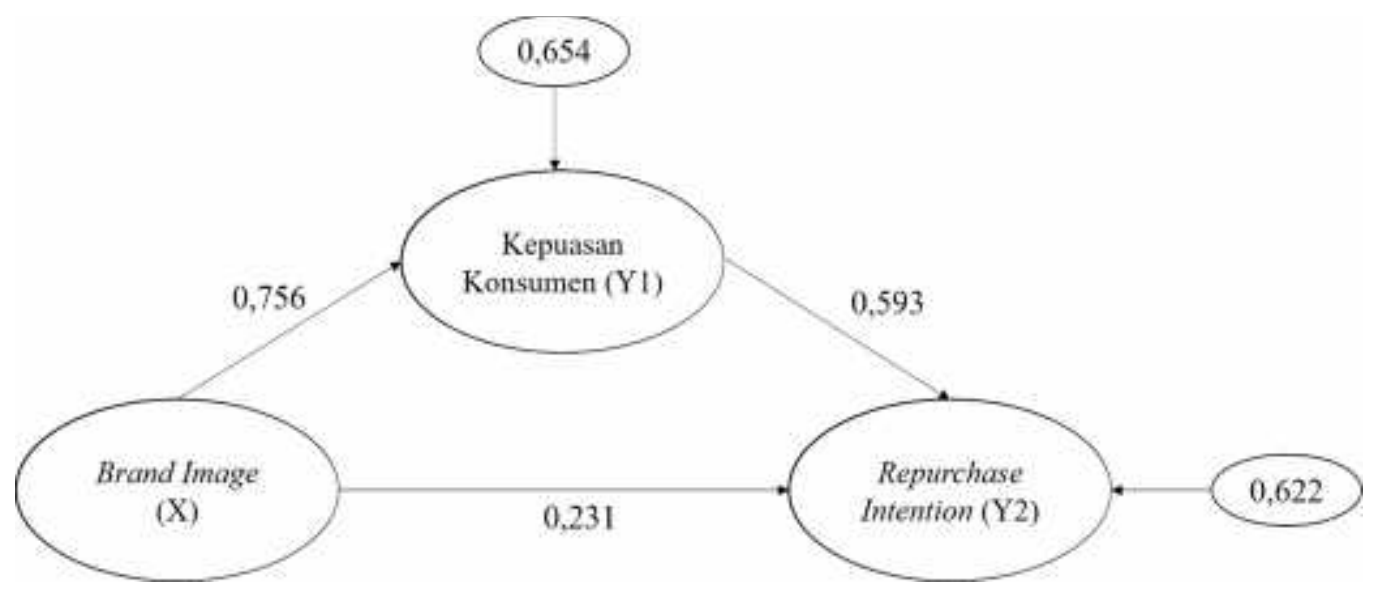

Gambar 2. Validasi Model Diagram Jalur Akhir

Sumber: Hasil olahan data, 2018

Berdasarkan Tabel 12 dapat dilihat bahwa brand image (X) mempunyai pengaruh secara langsung terhadap kepuasan konsumen $\left(\mathrm{Y}_{1}\right)$ sebesar 0,756. Brand image juga mempunyai pengaruh secara langsung terhadap repurchase intention $\left(\mathrm{Y}_{2}\right)$ yaitu sebesar 0,231 . Kepuasan konsumen juga mempunyai pengaruh secara langsung dengan repurchase inetntion sebesar 0,593. Disamping pengaruh secara langsung, brand image juga mempunyai pengaruh secara tidak langsung pada 
repurchase intention dengan melalui kepuasan konsumen yaitu sebesar 0,679. Berdasarkan hal tersebut dapat dilihat jika repurchase intention lebih besar dipengaruhi oleh kepuasan konsumen secara langsung dibandingkan brand image dan lebih besar total pengaruh secara tidak langsung antra brand image terhadap repurchase intention dengan melalui kepuasan konsumen dibandingkan tanpa melalui kepuasan konsumen.

Tabel 12.

Pengaruh Langsung dan Pengaruh Tidak Langsung serta Pengaruh Total Brand Image (X), Kepuasan Konsumen ( $\left.\mathrm{Y}_{1}\right)$, dan Repurchase Intention ( $\left.\mathrm{Y}_{2}\right)$

\begin{tabular}{cccc}
\hline $\begin{array}{c}\text { Pengaruh } \\
\text { Variabel }\end{array}$ & $\begin{array}{c}\text { Pengaruh } \\
\text { Langsung }\end{array}$ & $\begin{array}{c}\text { Pengaruh Tidak Langsung } \\
\text { melalui Kepuasan Konsumen } \\
\left(\mathbf{Y}_{\mathbf{1}}\right) \\
\left(\boldsymbol{\beta}_{\mathbf{1}} \mathbf{x} \boldsymbol{\beta}_{\mathbf{3}}\right)\end{array}$ & Pengaruh Total \\
\hline $\mathrm{X} \rightarrow \mathrm{Y}_{1}$ & 0,756 & & 0,756 \\
$\mathrm{X} \rightarrow \mathrm{Y}_{2}$ & 0,231 & 0,448 & 0,679 \\
$\mathrm{Y}_{1} \rightarrow \mathrm{Y}_{2}$ & 0,593 & & 0,593 \\
\hline
\end{tabular}

Sumber: Hasil olahan data, 2018

Uji hipotesis mediasi dilakukan dengan Uji Sobel. Apabila nilai z hitung > 1,96, dapat dikatakan variabel pemediasi dinilai secara signifikan mampu memediasi hubungan antara variabel independen dengan variabel dependen.

$$
\begin{aligned}
& \mathrm{Sab}=\sqrt{b^{2} S a^{2}+a^{2} S b^{2}+S a^{2} S b^{2}} \\
& \mathrm{Sab}=\sqrt{(0,433)^{2}(0,071)^{2}+(0,861)^{2}(0,066)^{2}+(0,071)^{2}(0,066)^{2}} \\
& \mathrm{Sab}=0,069 \\
& \mathrm{Z}=\frac{a b}{S a b} \\
& Z=\frac{(0,861)(0,433)}{0,069} \\
& \mathrm{Z}=5,358
\end{aligned}
$$


I G. A. Pt. Riana Pramesti Dewi, Peran Kepuasan Konsumen Memediasi...

Keterangan :

$\mathrm{Sab}=$ besarnya standar error tidak langsung

$\mathrm{Sa}=$ standar error koefisien a

$\mathrm{Sb} \quad=$ standar error koefisien $\mathrm{b}$

a $\quad=$ koefisien jalur $\mathrm{X}$ terhadap $\mathrm{Y}_{1}$

$\mathrm{b} \quad=$ koefisien jalur $\mathrm{Y}_{1}$ terhadap $\mathrm{Y}_{2}$

Berdasarkan perhitungan, diperoleh nilai z hitung sebesar 5,358 > 1,96 yang menandakan bahwa kepuasan konsumen dalam penelitian ini merupakan variabel yang mampu secara sigifikan memediasi hubungan antara brand image dan repurchase intention.

Selain dengan Uji Sobel, hasil pengujian mediasi juga menggunakan metode VAF. Apabila nilai VAF diatas 80 persen maka dapat dikatakan variabel pemediasi memiliki peran mediasi penuh. Apabila nilai VAF berkisar antara 20 hingga 80 persen maka dapat dikatakan pemediasi parsial. Namun apabila nilai VAF lebih kecil dari 20 persen maka bisa dijelaskan bahwa hampir tidak ada efek mediasi (Hair et al., dalam Solihin dan Ratmono, 2013). Berdasarkan perhitungan diperoleh nilai VAF sebesar 41,7 persen yang lebih besar dari 20 persen, maka dapat dijelaskan bahwa terdapat efek mediasi secara parsial.

$\mathrm{VAF}=\frac{b \times c}{(a+b \times c)}$

$\mathrm{VAF}=\frac{0,756 \times 0,593}{(0,625+(0,756 \times 0,593)}$

$\mathrm{VAF}=0,417$ atau 41,7 persen.

Kriteria pengujian dalam penelitian ini yang mana dapat menjelaskan pengaruh masing-masing variabel adalah apabila sig. $\mathrm{t}$ dibawah 0,05 maka $\mathrm{H}_{0}$ 
ditolak dan kemudian $\mathrm{H}_{1}$ diterima, dan sebaliknya apabila sig. $\mathrm{t}$ diatas 0,05 maka $\mathrm{H}_{0}$ diterima dan $\mathrm{H}_{1}$ ditolak. Tujuan pertama penelitian ini dilakukan yaitu untuk menjelaskan pengaruh hubungan brand image terhadap kepuasan konsumen. Bedasarkan hasil analisis, dapat dilihat bahwa brand image memiliki pengaruh secara positif serta signifikan terhadap kepuasan konsumen dengan $\beta_{1}$ bernilai 0,756 serta nilai signifikansi 0,000 . Berdasarkan hal tersebut, dapat dinyatakan bahwa $\mathrm{H}_{1}$ diterima. Hasil penelitian ini berindikasi bahwa beragam nilai yang ada di dalam brand image dengan baik dapat dipersepsikan oleh responden sehingga terbukti mampu meningkatkan kepuasan konsumen Chatime di Kota Denpasar, yang mana hal ini dapat diartikan bahwa apabila brand image yang dimiliki oleh Chatime semakin baik, maka akan mampu memberikan kontribusi untuk meningkatkan kepuasan konsumen. Thakur dan Singh (2012) berpendapat bahwa brand image akan mampu untuk dapat membentuk kepuasan konsumen dalam rangka untuk menciptakan pelanggan yang setia. Selain itu temuan dari penelitian ini juga memperkuat beberapa temuan penelitian terdahulu yang diungkapkan oleh Shahroudi dan Naimi (2014), Damayanti dan Wahyono (2015), serta Yana dkk. (2015) yang juga mengungkapkan bahwa adanya pengaruh yang positif serta signifikan anatara brand image terhadap kepuasan konsumen.

Tujuan lain dari penelitian ini yaitu untuk menjelaskan hubungan antara brand image dengan repurchase intention. Berdasarkan hasil penelitian, ditemukan adanya pengaruh yang positif serta signifikan antara brand image dengan repurchase intention dengan $\beta_{2}$ sebesar 0,231 dan 0,000 untuk nilai signifikansinya. Dengan demikian dapat dinyatakan bahwa $\mathrm{H}_{2}$ diterima. Hasil 
I G. A. Pt. Riana Pramesti Dewi, Peran Kepuasan Konsumen Memediasi...

penelitian ini berindikasi bahwa beragam nilai yang ada pada brand image dengan baik dapat dipersepsikan oleh responden sehingga memberikan dampak nyata terhadap repurchase intention, yang mana hal ini dapat dikatakan apabila brand image yang dimiliki Chatime semakin baik, maka akan mampu berkontribusi signifikan untuk meningkatkan repurchase intention. Hasil penelitian ini memperkuat beberapa temuan penelitian yang ditemukan oleh Chen dan Hsieh (2011), Ayutthaya (2013), Ain dan Ratnasari (2015), Soleha dkk. (2017), dan Sari dan Santika (2017) yang juga mengungkapkan bahwa brand image punya pengaruh yang positif serta signifikan terhadap repurchase intention.

Penelitian ini juga bertujuan untuk dapat menjelaskan hubungan antara kepuasan konsumen dengan repurchase intention. Berdasarkan hasil penelitian, dapat dilihat bahwa rupanya kepuasan konsumen punya pengaruh yang positif serta signifikan terhadap repurchase intention dengan $\beta_{3}$ bernilai 0,593 dan 0,000 untuk signifikansinya. Dengan begitu dapat dinyatakan bahwa $\mathrm{H}_{3}$ diterima. Dengan terciptanya kesesuaian antara harapan dengan kenyataan yang diterima konsumen, maka akan mampu membentuk suatu perasaan puas. Kepuasan dapat dikatakan sebagai respon positif yang diciptakan konsumen. Dengan semakin meningkatnya kepuasan yang diterima oleh konsumen maka akan mampu memberikan kontribusi yang signifikan pada repurchase intention konsumen. Temuan dari penelitian ini meperkuat beberapa hasil penelitian terdahulu seperti yang diungkapkan oleh Curtis et al. (2011), Ranjbarian et al. (2012), Huang et al. (2014), serta Kusuma dan Suryani (2017) yang juga mengungkapkan bahwa 
kepuasan konsumen punya pengaruh yang positif serta signifikan terhadap repurchase intention.

Penelitian ini juga bertujuan untuk memberikan penjelasan mengenai peran kepuasan konsumen dalam memediasi hubungan antara brand image terhadap repurchase intention. Berdasarkan hasil penelitian, ditemukan nilai z hitung dalam Uji Sobel sebesar 5,358 > 1,96. Hal tersebut berarti $\mathrm{H}_{4}$ dapat diterima yang berarti kepuasan konsumen mampu memediasi pengaruh variabel brand image terhadap repurchase intention konsumen Chatime di Kota Denpasar atau dengan kata lain dapat dikatakan bahwa brand image berpengaruh secara tidak lagsung terhadap repurchase intention melalui kepuasan konsumen. Berdasarkan hasil dari Uji VAF, ditemukan bahwa nilai VAF sebesar 41,7 persen yang menandakan kepuasan konsumen memberikan efek mediasi secara parsial. Brand image yang dimiliki Chatime dan juga didukung oleh tingkat kepuasan yang tinggi akan mampu memberikan pengaruh pada minat beli ulang konsumen terhadap Chatime. Dengan adanya brand image yang baik akan memiliki potensi untuk dapat mempengaruhi persepsi atau pandangan konsumen tentang Chatime yang pada akhirnya memberikan dampak bagi kepuasan konsumen. Pernyataan tersebut memperkuat temuan dari penelitian Susanti dan Wardana (2015) yang mengungkapkan bahwa rupanya terdapat pengaruh yang positif serta signifikan antara brand image dengan repurchase intention. Semakin baik atau semakin positif image yang dipersepsikan konsumen terhadap suatu brand, maka akan berpotensi untuk meningkatkan kepuasan konsumen saat bertransaksi dengan brand tersebut. Hasrat konsumen untuk melakukan pembelian ulang akan 
I G. A. Pt. Riana Pramesti Dewi, Peran Kepuasan Konsumen Memediasi...

terdorong dari rasa puas yang tinggi yang pernah dirasakan konsumen terhadap suatu produk. Hal tersebut diperkuat dengan hasil temuan dari penelitian yang dilakukan oleh Suandana dkk. (2016) serta Oktarini dan Wardana (2018) yang menyatakan bahwa kepuasan konsumen memiliki pengaruh yang positif serta signifikan dengan repurchase intention. Savitri dan Wardana (2018) pada penelitiannya memperoleh temuan bahwa kepuasan konsumen mampu memediasi pengaruh antara brand image terhadap repurchase intention. Brand image rupanya mampu menggerakkan kepuasan konsumen sehingga semakin baik brand image yang dimiliki oleh suatu produk atau perusahaan, maka akan semakin meningkat juga kepuasan konsumen. Kepuasan konsumen merupakan hal yang diyakini sebagai pendorong timbulnya repurchase intention pada konsumen.

\section{SIMPULAN DAN SARAN}

Berdasarkan hasil dari pembahasan tersebut, dapat dirangkum kesimpulankesimpulan yaitu brand image mempunyai pengaruh yang positif serta signifikan terhadap repurchase intention. Image yang positif dari suatu brand produk akan dapat menciptakan rasa aman bagi konsumen pada saat berhubungan dengan brand tersebut yang nantinya juga akan menciptakan suatu kepuasan konsumen. Brand image juga memiliki pengaruh yang positif serta signifikan dengan repurchase intention. Semakin baik dan positif citra yang melekat pada produk maupun perusahaan, akan berpotensi juga untuk meningkatkan keinginan konsumen untuk melakukan pembelian ulang atau bertransaksi dengan brand tersebut. Hal ini akan dapat berdampak pada hubungan antara produk atau perusahaan terhadap konsumen. Kepuasan konsumen berpengaruh secara positif 
serta signifikan pada repurchase intention. Tingginya rasa puas yang didapatkan oleh konsumen dari suatu produk atau perusahaan, akan dapat memicu munculnya niat beli ulang yang tinggi juga dalam diri konsumen terhadap produk yang sama. Kepuasan konsumen mampu memediasi pengaruh brand image terhadap repurchase intention. Hal ini menandakan bahwa kepuasan konsumen mampu memberikan dampak yang lebih besar terhadap hubungan antara brand image dengan repurchase intention. Brand image yang baik akan mampu menggerakkan kepuasan konsumen yang mana kepuasan konsumen merupakan faktor penting pemicu munculnya minat beli ulang konsumen terhadap suatu produk.

Berdasarkan hasil penelitian, adapun saran yang dapat diberikan adalah pihak manajemen Chatime harus meningkatkan dan memperkuat brand image yang dimiliki Chatime, mengingat Chatime bukanlah produk yang baru lagi di pasaran. Pihak manajemen Chatime dapat mengupayakan untuk memperkuat brand image dengan cara menyebarluaskan informasi atau hal-hal positif yang dilakukan Chatime lebih luas lagi kepada masyarakat sehingga dapat menambah pengetahuan masyarakat mengenai track record positif yang dimiliki Chatime yang mana hal tersebut akan mampu memberikan nilai tambah bagi Chatime dan menambah keyakinan konsumen terhadap Chatime. Pihak manajemen Chatime juga sebaiknya memperkuat emotional factor antara Chatime dengan konsumen sehingga tercipta hubungan emosional pada saat konsumen bertransaksi dengan Chatime. Hubungan emosional tersebut dapat berupa rasa bangga atau kagum pada diri konsumen pada saat mengkonsumsi ataupun melakukan pembelian terhadap Chatime. Hal ini dapat diupayakan dengan membuat bauran pemasaran 
I G. A. Pt. Riana Pramesti Dewi, Peran Kepuasan Konsumen Memediasi...

Chatime yang lebih exclusive sehingga menciptakan wajah baru pada Chatime yang diharapkan mampu meningkatkan hubungan emosional antara Chatime dengan konsumen yang mana hal tersebut akan dapat berdampak kepada kepuasan. Pihak manajemen Chatime juga harus memperhatikan dan mengupayakan minat beli ulang konsumen terhadap Chatime mengingat sudah banyak produk-produk sejenis yang beredar luas di masyarakat yang mana hal tersebut akan menjadi pesaing besar bagi Chatime. Chatime dapat menangani hal ini dengan terus melakukan inovasi terhadap produknya. Disamping itu, Chatime juga sebaiknya terus memperhatikan kualitas produk sehingga tercipta diferensiasi antara produk Chatime dengan produk sejenis dari merek lainnya. Chatime juga dapat meningkatkan frekuensi iklan yang ditampilkan kepada konsumen untuk menyadarkan konsumen akan keberadaan Chatime sehingga diharapkan dapat menimbulkan keinginan dan ketertarikan konsumen untuk melakukan pembelian.

\section{REFERENSI}

Ain, N., \& Ratnasari, R. tri. (2015). Pengaruh citra merek melalui sikap konsumen terhadap niat beli ulang pada produk busana muslim zoya disurabaya. JESTT Universitas Airlangga, 2(7), 553-569.

Arimbawa, S. I. G., \& Ekawati, N. W. (2017). Pengaruh Penerapan Green Marketing terhadap Citra Merek dan Keputusan Pembelian Produk. E-Jurnal Manajemen Unud, 6(5), 2582-2608.

Astuti, N. (2016). Hubungan Citra Merek dengan Loyalitas Merek pada KonsumenMobil PT. Honda Semoga Jaya Samarinda. E-Jurnal Psikologi Fisip Universitas Mulawarman, 4(3), 439-448.

Ayutthaya, S. S. N. (2013). Impact of Perceived Service Brand Image and Repurchase Intentions of Thai Passengers Towards Low Cost Carriers. Journal of Management, 11(2), 46-56.

Cengiz, E. (2010). Measuring Customer Satisfaction : Must or Not? Journal of 
Naval Science and Engineering, 6(2), 76-88.

Chen, H.-S., \& Hsieh, T. (2011). A Study of Antecedents of Customer Repurchase Behaviors in Chain Store Supermarkets. Journal of International Management Studies, 6(3), 1-11.

Choi, E. J., \& Kim, S. H. (2013). The study of the impact of perceived quality and value of social enterprises on customer satisfaction and re-purchase intention. International Journal of Smart Home, 7(1), 239-252.

Curtis, T., Beach, D., Abratt, R., Huizenga, H. W., \& Rhoades, D. (2011). Customer Satisfaction, Loyalty and Repurchase: Some Evidence from Apparel Consumers. Review of Business, 32(1), 47-58.

Damayanti, C., \& Wahyono. (2015). Pengaruh Kualitas Produk, Brand Image terhadap Loyalitas dengan Kepyasan Sebagai Variabel Intervening. Management Analysis Juournal Universitas Negeri Semarang, 4(3), 236251.

Darmawan, P. A. D., \& Ekawati, N. W. (2017). Pengaruh Kepuasan Konsumen Memediasi Harga terhadap Loyalitas Konsumen dalam Berbelanja pada Florist Online di Denpasar. E-Jurnal Manajemen, 6(4), 2076-2104.

Diponugroho, A., \& Santoso, S. B. (2015). Analisis Pengaruh Kualitas Produk dan Kemampuan Inovasi terhadap Minat Beli Ulang dengan Daya Tarik Produk Sebagai Variabel Intervening (Studi pada Parlour Café Semarang). Diponegoro Journal of Management, 4(3), 1-9.

Dwiputranto, M. R. H. (2017). Pengaruh Brand Image dan Product Quality terhadap Brand Love dan Brand Loyalty pada Pengguna Mobil Honda Jazz di Kota Pekanbaru. Journal of Marketing Fekon, 4(1), 297-310.

Herliza, R., \& Saputri, M. E. (2016). Pengaruh Brand Image terhadap Kepuasan Pelanggan Studi pada Zara di Mall PVJ Bandung. E-Proceeding of Management, 3(2), 1949-1955.

Huang, C.-C., Yen, S.-W., Liu, C.-Y., \& Chang, T.-P. (2014). The Relationship Among Brand Equity, Customer Satisfaction, and Brand Resonance To Repurchase Intention of Cultural and Creative Industries in Taiwan. The International Journal of Organization Innovation, 6(2014), 106-121.

Kusuma, P. D., \& Suryani, A. (2017). Peran Customer Satisfaction Memediasi Pengaruh Marketing Mix terhadap Repurchase Intention. E-Jurnal Manajemen Unud, 6(3), 1398-1424.

Lee, M.-C. (2010). Explaining and predicting users' continuance intention toward 
I G. A. Pt. Riana Pramesti Dewi, Peran Kepuasan Konsumen Memediasi...

e-learning: An extension of the expectation-confirmation model. Computers and Education, 54(2), 506-516.

Meng, S.-M., Liang, G.-S., \& Yang, S.-H. (2011). The relationships of cruise image, perceived value, satisfaction, and post-purchase behavioral intention on Taiwanese tourists. African Journal of Business Management, 5(1), 1929.

Moksaoka, I. M. W., \& Rahyuda, I. K. (2016). Peran Brand Image dalam Memediasi Country of Origin terhadap Purchase Intention. E-Jurnal Manajemen Unud, 5(3), 1690-1716.

Nikbin, D., Ismail, I., Marimuthu, M., \& Abu-Jarad, I. Y. (2011). The impact of firm reputation on customers' responses to service failure: The role of failure attributions. Business Strategy Series, 12(1), 19-29.

Oktarini, M. A., \& Wardana, I. M. (2018). Peran Customer Satisfaction Memediasi Pengaruh Perceived Ease of Use dan Perceived Enjoyment terhadap Repurchase Intention. E-Jurnal Manajemen Unud, 7(4), 20412072.

Palaguna, I. G. N. F., \& Ekawati, N. W. (2016). Green Promotion Memediasi Greeen Packaging terhadap Repurchase Intention (Studi pada AMDK ADES di Kota Denpasar). E-Jurnal Manajemen Unud, 5(12), 7500-7527.

Pechyiam, C., \& Jaroenwanit, P. (2014). The Factors Affecting Green Brand Equity of Electronic Products in Thailand. The Macrotheme Review, 3(9), 112.

Prastiwi, S. K. (2016). Menguji Faktor-Faktor Yang Berpengaruh Terhadap Repurchase Intention Pada Produk Mie Instan Indomie Di Yogyakarta. Jurnal EKA CIDA, 1(1), 96-109.

Prastyaningsih, A. S., Suyadi, I., \& Yulianto, E. (2014). Pengaruh Customer Experience Terhadap Repurchase Intention (Survei pada Konsumen KFC Di Lingkungan Warga RW 3 Desa Kandangrejo, Kedungpring, Lamongan). Jurnal Administrasi Bisnis (JAB), 16(1), 1-8.

Pupuani, N. W., \& Sulistyawati, E. (2013). Pengaruh Bauran Pemasaran Terhadap Kepuasan Konsumen dan Perilaku Pembelian Ulang (Studi Kasus pada Produk Pasta Gigi Merek Pepsodent di Kota Denpasar). E-Jurnal Manajemen Universitas Udayana, 2(6), 683-702.

Ranjbarian, B., Sanayei, A., Kaboli, M. R., \& Hadadian, A. (2012). An Analysis of Brand Image, Perceived Quality, Customer Satisfaction and Re-purchase Intention in Iranian Department Stores. International Journal of Business 
and Management, 7(6), 40-48.

Sari, N. K. L., \& Santika, I. W. (2017). Pengaruh Brand Image, Brand Assocation, dan Brand Awareness terhadap Repurchase Intention Produk Smarthphone Merek Asus. E-Jurnal Manajemen Unud, 6(8), 4099-4126.

Savitri, I. A. P. D., \& Wardana, I. M. (2018). Pengaruh Citra Merek, Kualitas Produk dan Persepsi Harga terhadap Kepuasan dan Niat Beli Ulang. E-Jurnal Manajemen Unud, 7(10), 5748-5782.

Shahroudi, K., \& Naimi, S. S. (2014). The Impact of Brand Image on Customer Satisfaction and Loyalty Intention (Case Study: Consumer of Hygiene Products). International Journal of Engineering Innovation \& Research, 3(1), 57-61.

Soleha, I., Arifin, R., \& Rahmad, S. A. (2017). Pengaruh Citra Merek Dan Persepsi Label Halal Terhadap Minat Pembelian Ulang Produk Kosmetik Zoya Malang. Jurnal Riset Manajemen, 6(2), 166-176.

Suandana, N. P. W., Rahyuda, K., \& Yasa, N. N. K. (2016). Pengaruh Pengalaman Membeli Produk Fashion terhadap Niat Membeli Kembali Melalui Kepuasan dan Kepercayaan Pelanggan. Jurnal Manajemen, Strategi Bisnis Dan Kewirausahaan, 10(1), 85-97.

Susanti, N. P. H., \& Wardana, I. M. (2015). Pengaruh Kualitas Produk Dan Citra Merek Terhadap Kepuasan Dan Loyalitas Pelanggan Pada Produk Kosmetik Hijau Merek the Body Shop. Jurnal Ilmu Ekonomi Dan Sosial, 1(2), 622636.

Thakur, S., \& Singh, A. P. (2012). Brand Image, Customer Satisfaction and Loyalty Intention : a Study in the Context of Cosmetic Product. International Journal of Multidisciplinary Management Studies, 2(5), 37-50.

Top Brand Award. 2017. Top Brand for Teens Index 2017. Diunduh pada tanggal 28 Februari 2018. http://www.topbrand-award.com/top-brand-survey/surveyresult/top_brand_for_teens_index_2017

2018. Top Brand for Teens Index 2018. Diunduh pada tanggal 28 Februari 2018.http://www.topbrand-award.com/top-brand-survey/surveyresult/top_brand_for_teens_index_2018,

Varga, A., Dlacic, J., \& Vujicic, M. (2014). Repurchase Intentions in A Retail Store - Exploring The Impact of Colours. Ekonomski Vjesnik, 27(2), 229244.

Wang, C. Y., \& Lin, C. H. (2010). A Study of The Effect of TV Drama on 
I G. A. Pt. Riana Pramesti Dewi, Peran Kepuasan Konsumen Memediasi...

Relationship Among Tourist's Experiential Marketing, Experiential Value and Satisfaction. The International Journal of Organizational Innovation, 2(3), 107-124.

Wijaya, I. P. S. A., \& Nurcaya, I. N. (2017). Kepuasan Pelanggan Memediasi Kualitas Produk Dan Kewajaran Harga Terhadap Loyalitas Merek Mcdonalds Di Kota Denpasar. E-Jurnal Manajemen Unud, 6(3), 1534-1563.

Yana, R. D., Suharyono, \& Abdillah, Y. (2015). Pengaruh Citra Merek terhadap Kepuasan Pelanggan dan Loyalitas Pelanggan (Survei Pada Konsumen Produk Busana Muslim Dian Pelangi Di Malaysia). Jurnal Administrasi Bisnis, 21(1), 1-7. 